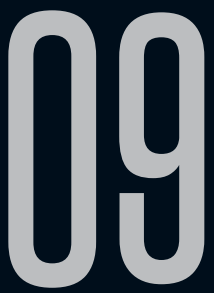

\title{
VAMPIRISMO E CLAUSURA DO DESEJO EM O DESCONHECIDO E ANGÉLICA, DE LÚCIO CARDOSO
}

Fernando Monteiro de Barros (UERJ-FFP) Leonardo Ramos Botelho Gomes (UERJ-FFP)

Recebido em 17 mar 2019. Fernando Monteiro de Barros é Professor Adjunto Aprovado em 14 mai 2019. de Literatura Brasileira na Faculdade de Formação de Professores da UERJ, onde atua no Programa de PósGraduação em Letras e Linguística (PPLIN) e desenvolve pesquisa sobre literatura gótica brasileira. É membro pesquisador do grupo (CNPq) Estudos do Gótico.

Leonardo Ramos Botelho Gomes é Mestrando em Estudos Literários do Programa de Pós-Graduação em Letras e Linguística (PPLIN), da Faculdade de Formação de Professores da UERJ, onde desenvolve pesquisa sobre os aspectos góticos no teatro de Lúcio Cardoso, sob a orientação do professor Fernando Monteiro de Barros.

Resumo: Lúcio Cardoso (1912-1968) é um escritor mineiro que apresenta em sua obra uma presença marcante de muitos elementos derivados da tradição literária do Gótico. O tema do vampirismo aparece tanto em um sentido metafórico na obra de Lúcio como na novela $O$ desconhecido, de 1940 - quanto no sentido literal, com aspectos plenamente calcados no sobrenatural, como na peça teatral Angélica, de 1950. Ambos os textos apresentam um traço específico do vampirismo, o daquele no qual a criatura, desprovida 
de qualquer beleza ou atratividade sexual, adota o comportamento de uma ave de rapina, a fim de dar vazão ao desejo enclausurado. Tal traço confere a estas obras uma dimensão ontológica, condizente com a categoria de autor de romances psicológicos na qual Lúcio Cardoso é enquadrado pelo cânone literário brasileiro.

Palavras-chave: Lúcio Cardoso; Literatura Gótica; Desejo; Vampirismo.

Abstract: Lúcio Cardoso (1912-1968) is a Brazilian author from Minas Gerais who shows in his work a remarkable presence of many elements derived from the Gothic tradition in literature. The theme of vampirism comes both in a metaphorical sense in Lúcio's work - as in the novel $O$ desconhecido (The unknown one), published in 1940 - and in a proper sense, in full-fledged supernatural colors, as in the play Angélica, written in 1950. Both texts depict a specific strain of vampirism, that of a creature who, devoid of any beauty or sex-appeal, adopts the behavior of a bird of prey, in order to let out the desire repressed within. That trait lends to these works an onthological dimension, in accordance with the psycological category where Lúcio Cardoso stands in the canon of Brazilian Literature.

Keywords: Lúcio Cardoso; Gothic Literature; Desire; Vampirism.

Lúcio Cardoso (1912-1968) é um escritor brasileiro do século XX em cuja obra são muito fortes os influxos da tradição gótica que se estabeleceu na literatura ocidental a partir do romance $O$ castelo de Otranto, do autor inglês Horace Walpole, publicado em 1764. Além disso, em sua produção literária é frequente a presença de personagens com vários traços vampirescos. Como afirma Nina Auerbach (1995, p.5), o vampiro não é um personagem monolítico, 
pois em cada ocorrência desse personagem na literatura ou no cinema este assume características diferentes, podendo ser belo e sedutor como os vampiros de John Polidori (The Vampyre, 1819) e Lord Byron (Fragment of a Novel, 1819), mas também grotesco e repelente, como o Conde Orlock do filme Nosferatu, do diretor alemão F. W. Murnau, de 1922. Dentre os vários personagens vampirescos de Lúcio Cardoso, destacamos aqui Aurélia, da novela O desconhecido (1940), e Angélica, do drama teatral homônimo de 1950, uma vez que, dentro da voltagem intratextual da obra de Lúcio, as duas personagens apresentam vários traços convergentes.

A presença do Gótico é ostensiva na obra de Lúcio Cardoso. Já o fantástico ocorre muito raramente na sua narrativa, porém mais frequentemente em seus dramas teatrais. No romance que inaugura a fase intimista de Lúcio, A luz no subsolo, de 1936, temos a presença do personagem espectral "mendigo resignado" (BARROS JUNIOR, 2002, p.43) e em quase toda a produção dramática do autor temos personagens que em um primeiro momento aparentam ser igualmente sobrenaturais. Contudo, na maior parte da obra de Lúcio o sobrenatural acaba sendo desconstruído por uma explicação racional, como sendo produto da loucura delirante dos personagens, revelando ser, assim, muito mais a ocorrência do estranho (TODOROV, 1975, p.48). Há, contudo, exceções, como o drama teatral Angélica, que mantém a presença do sobrenatural até o fim.

A grande maioria dos personagens do escritor mineiro manifesta um forte traço de transgressão aos valores da sociedade brasileira da época, marcada por um forte conservadorismo burguês (anos 30, 40 e 50 do século XX). Lúcio era um intelectual que não aderia 
a este etos e nem tampouco nutria simpatia pela ideologia de esquerda. Desviante ao extremo, o pensamento político de Lúcio assemelhava-se ao de Baudelaire e ao dos escritores decadentistas franceses do final do século XIX, em seu desdém pelos valores democráticos e em seu culto à aristocracia. Não por acaso, sua obra apresenta um forte legado do imaginário gótico e da poética do Decadentismo, estilos literários afins, marcados pelo mote da majestade em ruínas e pelo entrecruzamento de sexualidade e morbidez, que tem no vampirismo a sua principal metáfora. Assim como no Gótico, o espaço assume importância capital na obra de Lúcio Cardoso, que enfatiza a criação de uma atmosfera tenebrosa, ao evocar ambientes decadentes, tanto provincianos quanto urbanos, representantes de uma tradição extinta que teima em permanecer na modernidade.

A narrativa de $O$ desconhecido, denominada "novela" e não "romance" por seu autor, tem como protagonista um homem atormentado, de passado infeliz, que troca a cidade pela província, e vai exercer uma função subalterna na fazenda arruinada e decadente de Aurélia, uma senhora aristocrática e soturna. $\mathrm{O}$ aspecto central do enredo é que tanto Aurélia quanto José Roberto (o "desconhecido" do título) sofrerão uma espécie de enclausuramento desejante compulsório pelo motivo de não serem dotados de beleza, o que contrasta fortemente com a situação dos personagens Paulo, empregado da fazenda, e Nina, filha da criada de Aurélia, ambos jovens, belos e apaixonados, que são caracterizados ao longo da trama como seres que vivem completamente livres. Paulo acaba se tornando o objeto amoroso de José Roberto, enquanto sua namorada Nina é expulsa da 
fazenda por inveja de Aurélia, que, por sua vez, vislumbra em José Roberto a possibilidade de dar vazão a seu desejo.

O enredo enfatiza, assim, a oposição entre beleza/liberdade e fealdade/enclausuramento. A majestosa dona da fazenda sofre com "o mistério da sua vida, a força de seu destino solitário" (CARDOSO, 1969, p.163), por reconhecer como causa de seu infortúnio o fato de que "toda ela era repelente" (p.167). Enquanto crescera "isolada no ambiente abafado de uma família em decadência, uma dessas pobres flores envenenadas pelas atmosferas em decomposição" (p.169), corroída pelo "desejo mortal de viver o mais intensamente possível" (p.169), Nina, por sua vez, fora crescendo "solta por aí, como um bicho selvagem" (p.123) até o dia em que Aurélia "encontrou-a se banhando no rio" (p.123) e, invejosa de sua beleza, após tentar com uma grande tesoura cortar-lhe os cabelos, expulsou-a da fazenda (p.123). A inveja que Aurélia sente dos atributos físicos de Nina é explicitada quando afirma: "Não posso vê-la, não posso nem sequer lembrar-me de que ela existe. É jovem, é bela..." (p.166). Ao que acrescenta, desolada:

Como é bela, meu Deus, como é bela! Nunca vi na minha vida cabelos iguais, pele mais sedosa, olhos mais brilhantes. Nunca vi fascinação mais poderosa. Pensei em deixar tudo, em me recusar a tomar um partido definido. Mas a pequena crescia a olhos vistos, criava formas, atraía todos os olhares, invadia a fazenda inteira com o seu esplendor. Onde quer que fosse, eu a via, estuante de saúde. Como era possível viver desse modo, eu, que nunca tive nada, que sempre fui feia e escarnecida? Não tive forças para perdoá-la. Expulsei-a. [...] Essa menina é uma negação da minha própria existência. (CARDOSO, 1969, p.171) 
No Ocidente tributário da hegemonia do pensamento apolíneo, ratificado pela metafísica platônica que equiparava a beleza à razão, à verdade e à divindade (PLATÃO, 1989, p.64-69), os velhos, os feios e os fisicamente repulsivos, nas narrativas tradicionais, sempre se encontraram dificultados no acesso a Eros. Nas narrativas ocidentais, a dicotomia entre heroísmo e vilania tradicionalmente sempre pressupôs atributos de beleza nos heróis, brindados ao final com o amor, e características de fealdade nos vilões, quase nunca amantes ou amados. Por outro lado, nos rituais que celebravam os mistérios dionisíacos, a dissolução das fronteiras do que seria o ego individual se dava, além de na embriaguez e na loucura sagrada, também na orgia, na qual Eros se democratizava (PAGLIA, 1992, p.99-100), permitindo o seu acesso a todos, independentemente de serem dotados ou não de beleza. O sofrimento de José Roberto e Aurélia na narrativa de $O$ desconhecido atesta o exílio amoroso dos não dotados de beleza física nas narrativas da civilização apolínea ocidental, condenados a experimentarem o desejo enquanto clausura.

No entanto, Aurélia e José Roberto mal conseguem controlar o incontrolável: a voracidade de seus desejos de fusão erótica. Sem saber da inclinação homoafetiva de José Roberto, Aurélia projeta sobre ele seus arroubos desejantes, o que por ele é percebido: "José Roberto não se enganava: sentia nela a contenção das feras, que estudam antes o salto para não perderem a presa" (CARDOSO, 1969, p.160).

Atestando o dado ostensivamente cenográfico do vampirismo literário (FRAYLING, 1991, p.6), mero fingimento poético, o enredo sugere contornos vampíricos ao personagem de Aurélia a partir das poses do gênero. No começo da narrativa de $O$ desconhecido, José Roberto, ao ver Aurélia pela primeira vez dentro do coche em 
que era conduzida pela estrada poeirenta, "percebeu que uma mão descarnada tinha-se pousado no rebordo da janela, e, examinando-a bem, viu que qualquer coisa emprestava a esses dedos afilados uma particular expressão de avidez", como se os dedos de Aurélia "estivessem tateando os objetos, numa carícia silenciosa de quem ocultasse ao mesmo tempo a sinistra intenção de devorálos" (CARDOSO, 1969, p.116). Estas mesmas mãos de Aurélia são também referidas na narrativa como "garras abertas" (p.164). O aristocratismo dos vampiros da literatura também se faz presente, pois "um anel de prata, com um enorme rubi, parecia comunicar a essa mão uma nobreza gelada" (p.116). Ao finalmente conseguir vislumbrar o seu rosto, José Roberto percebeu que Aurélia "era uma mulher de idade, vestida de escuro, a gola alta presa por uma pedra idêntica à que trazia no dedo. De cabeça erguida, toda ela parecia irradiar uma sombria e desdenhosa majestade" (p.116). Embora não pudesse "ver detidamente os traços de sua fisionomia", "sobravaIhe em compensação a sugestão avermelhada do ambiente, feita pelo reflexo da lanterna e pelo veludo escuro que forrava as almofadas do banco e que parecia mergulhar aquela figura solitária numa espécie de atmosfera diabólica" (p.116). A caracterização de Aurélia, assim, reveste a personagem de feições vampirescas e com os atributos de uma ave de rapina.

A esse respeito, Luiz Costa Lima, ao analisar a obra de Cornélio Penna, escritor da mesma lavra de Lúcio Cardoso, conceitua a violência da sexualidade enclausurada a partir da metáfora da ave de rapina, noturna, sempre à espreita para cravar suas garras quando o momento se apresenta propício (LIMA, 1976, p.70). Em Fronteira, primeiro romance de Cornélio, publicado em 1935, a 
personagem Maria Santa, considerada milagreira pela população do lugarejo mineiro em que vive, não tem outra forma de dar vazão ao furor de sua mal contida sexualidade, conforme diz o Narrador, alvo dos arroubos da jovem beata. O trecho abaixo citado é extraído do capítulo XXXIV, que começa com um passeio que o Narrador e Maria Santa dão no jardim "silencioso e devastado", tarde da noite. O Narrador diz a Maria Santa para irem embora, já que um arrepio os faz estremecer:

- Mas você é que está com medo... - respondeume, e deu uma risada clara, mas logo imobilizou-se, rígida, à escuta, como se esperasse a resposta ao seu desafio.

Depois, afastou-se de mim, e perdeu-se na sombra, que se tornara espessa, compacta, como se tivesse caído sobre mim um bloco de massa negra.

Fiquei por muito tempo esperando, à espreita, a perscrutar ansiosamente em torno, e sentia cada vez mais longe, cada vez maior o meu abandono.

[...]

Senti, depois, uma mão trêmula agarrar-me o braço, e unhas, em garra, enterraram-se na minha carne. Um bafo quente chegou-me até a boca, adocicado e morno, e senti que todo o meu corpo se encostava a outro corpo, em um êxtase doloroso e longo, inacabado e insatisfeito...

Quando voltei a mim, procurei afastar com violência o monstro que viera das trevas, mas estava só de novo, e voltei para casa, sem procurar explicar o que me sucedera... (PENNA, 1958, p.65)

Com relação à passagem supracitada, assegura Costa Lima que podemos "associar o uso das garras aos espasmódicos acessos de 
febre sexual da personagem" (LIMA, 1976, p.70). "Garras" são, pelo crítico, associadas à "ave noturna", à "espreita" e à "violência da sexualidade". Ao concluir que "o próprio da ave de rapina é o uso de garras", Costa Lima elege, assim, o paradigma da ave de rapina como metáfora por excelência desta configuração da violência da sexualidade (LIMA, 1976, p.70). De fato, em $O$ desconhecido, em um dado momento a narrativa se refere a Aurélia como possuidora de um "cruel perfil de ave de rapina" (CARDOSO, 1969, p.133).

Esta modalidade violenta, noturna e predatória do desejo sexual tem, desde a literatura gótica do final do século XVIII, sua mais recorrente metáfora no vampiro, figura mítica legada pelo Romantismo (GLADWELL, 1999, p.7). Enfeixando o amor e a morte (GLADWELL, 1999, p.7), os vampiros têm uma ligação indiscutivel com as potências daimônicas de Eros: o romance Drácula, de 1897, coloca como principal ameaça do vampirismo a insaciabilidade de seu desejo sexual (HINDLE, 1993, p.IX), tão mais ameaçador por ser percebido enquanto força incontrolável da natureza em sua indiferença arcaica (BELSEY, 1994, p.176-177). Neste sentido, os vampiros apresentam uma dimensão dionisíaca indiscutível e, curiosamente, além do próprio deus Dioniso também ter sido associado, por Eurípides, em As bacantes, a um caçador sedento de sangue (OTTO, 1995, p.109), os rituais em sua homenagem culminavam na omofagia, ou seja, a "consumação imediata do sangue e da carne crua" da vítima sacrificial, geralmente um touro ou um bode, após seu dilaceramento (diasparagmós, em grego) pelos praticantes do culto (BRANDÃO, 1988, p.137).

São várias as representações do vampiro, na literatura ocidental, e também no cinema, enquanto predador sexual noturno 
e oportunista, que estuda cuidadosamente a vítima e se lança ao ataque quando o momento se mostra propício, tal como fazem as aves de rapina. Em Aurélia, seus traços vampíricos se traduzem na necessidade de dissolver aquilo que na cultura ocidental, desde a época clássica em Atenas, constituía o princípio de individuação, que era rompido pelo sparagmós dionisíaco, já que na narrativa a aristocrática senhora da fazenda "precisa de alguém, de uma alma que seja sua, que esteja sob o seu domínio como um objeto que pode ser estraçalhado a qualquer momento" (CARDOSO, 1969, p.224), perpassada que é pelo "mais animal dos desejos, a mais violenta e a mais inútil das paixões, esse absurdo e tenebroso desejo de posse, essa vontade de reduzir e aniquilar, que nos habita como o mais diabólico sinal da natureza humana" (p.225). Não logrando seu intento, entretanto, Aurélia permanece durante toda a trama "encerrada dentro de si mesma, como num inviolável sepulcro" (1969, p.223), amargando "o mistério da sua natureza solitária, mergulhada nas trevas, sem nenhuma crença, sem nenhum amparo, sem outro caminho que o seu perpétuo rancor" (1969, p.223).

O vampirismo enquanto metáfora da clausura do desejo, no entanto, adquire nesta novela dimensões ontológicas e existenciais mais amplas: "A solidão daquela mulher pareceu-lhe um monstruoso castigo. Mas não pertencia somente a ela, como um abominável privilégio, era uma espécie de maldição lançada sobre o gênero humano" (1969, p.227). A seguinte passagem da Imitação de Cristo, texto medieval da Igreja Católica, já reconhecia o corpo como clausura, submetido à tirania do desejo sem fim:

Em verdade, grande miséria é viver na terra. Comer, beber, velar, dormir, descansar, trabalhar, 
estar sujeito às demais necessidades da natureza é, de fato, grande miséria e aflição para o homem... muito oprimido se sente, com efeito, o homem interior com as necessidades do corpo. (KEMPIS, 1948, p.44)

A literatura acabou dando contornos eróticos e aristocráticos ao mito do vampirismo, inexistentes na tradição folclórica a respeito (TWITCHELL, 1997, p.7), segundo a qual os vampiros eram camponeses mortos que voltavam de suas tumbas apenas para sugar o sangue de seus familiares ainda vivos, ou seja, tendo como finalidade última apenas aplacar a sua sede omofágica. Em pleno século XVIII, no momento em que o lluminismo está prestes a proclamar a supremacia da máxima cartesiana e da objetividade da verdade, surgem na imprensa, nos decênios de 1720 e 1730, relatos sobre casos de vampirismo em aldeias do leste europeu. É a poesia alemã que inaugura a linhagem literária dos vampiros, a partir de "Der Vampir" (1748), de Heinrich August Ossenfelder, "Lenore" (1773), de Gottfried August Burger e "Die Braut von Korinth" ("A Noiva de Corinto", 1797), de Goethe (TWITCHELL, 1997, p.33). Principalmente em "Lenore" e no poema de Goethe, a fome do vampiro é de "amor, não de sangue" (p.34).

O mito do vampiro, assim, se solidificou no imaginário ocidental não só pela tradição folclórica e subsequentes relatórios oficiais e médicos documentados por toda a Europa no século XVIII, mas, principalmente, por suas diversas manifestações artísticas, culminando com as cinematográficas, e contando com uma extensa tradição literária, que surge nos setecentos, percorre a literatura penny-dreadful oitocentista, até os romances de uma Anne Rice, por exemplo. A revisitação de produções literárias da temática 
do vampirismo ressalta, curiosamente, que as abordagens iniciais do vampiro na literatura são fundamentadas na figura feminina, sobretudo na produção poética, como confirmam Martha Argel e Humberto Moura Neto (2008, p.25).

Théophile Gautier, Bram Stoker e Sheridan Le Fanu também são exemplos de escritores que solidificaram o tema da mulher vampiro, da qual seria também a origem da vamp moderna, definida pelo Shorter English Dictionary como: "uma mulher que se esforça para encantar ou cativar os homens (frequentemente por razões desonestas ou discutíveis) utilizando sua atração sexual sem escrúpulos" (Apud LECOUTEUX, 2005, p.30). Em geral, conforme salienta Claude Lecouteux, "de uma fria crueldade, exigindo abandono total e volúpia", estas mulheres "se deleitam com a dor e a lenta agonia da vítima" (2005, p.30).

A balada de Goethe "A Noiva de Corinto", que, segundo Mario Praz, seria o primeiro comparecimento literário sério do tema do vampirismo (PRAZ, 1996, p.89), vincula a sede de amor vampírica à clausura. Em vinte e oito estrofes, o poema narra o ataque vampírico sofrido por um jovem rapaz, vítima da sede de amor da Noiva de Corinto do título, que, neste texto fundador, já adota a postura de ave de rapina (GOETHE, 1999, p.110-121):

Porém, do aprisionamento de minha tumba, Por uma lei extraordinária sou forçada a sair e vagar Enquanto as bênçãos e os cânticos de seus padres Se mostram ineficazes;

O sal e a água em vão tentam Subordinar os sentimentos ardentes.

Ah, nem mesmo a terra pode esfriar o amor!

Este rapaz fora primeiro prometido para mim Enquanto o alegre templo de Vênus ainda existia. Mãe, quebraste a tua palavra 
Constrangida por um falso e estrangeiro voto.

Mas os deuses não escutam

Quando uma mãe promete

Negar a mão de sua filha prometida.

Sou forçada a sair de meu túmulo

Para continuar a ir atrás das coisas boas de que sinto falta,

Para continuar a amar o homem já perdido,

E sugar o sangue vital de seu coração.

Se agora ele está condenado,

Devo procurar outros

Os jovens sucumbirão à minha fúria.

Belo rapaz! Tu não podes mais viver;

Irás definhar neste leito.

Eu te dei o meu cordão;

Eu levarei comigo um cacho de teus cabelos

Mira-o bem!

Amanhã estarás grisalho,

E apenas aí teu cabelo permanecerá castanho.

Os versos acima explicitam a conexão não apenas entre vampirismo e erotismo, mas também entre desejo e clausura. O poema parece também estabelecer um elo entre vampirismo e as potências dionisíacas, pois deixa claro que os alegres e festivos deuses pagãos, Ceres, Baco (Dioniso) e Vênus, são substituídos pelo cristianismo "dos Céus", mas em vão, pois os decretos do alto não conseguem sufocar o desejo daimônico que ferve mesmo "embaixo da terra" (GOETHE, 1999, p.110-121). O céu patriarcal não consegue, assim, submeter a terra matriarcal, apesar das preces e cânticos dos padres. E, assim como Aurélia de $O$ desconhecido, a "noiva" de Corinto se sente furiosa por sua clausura impedi-la de participar do jogo erótico e amoroso do mundo cristianizado e apolinizado, vingando-se, portanto, com 
o jugo e a destruição que exerce sobre os homens que caem em suas garras.

O poema também parece estabelecer, na literatura ocidental, a partir do próprio mito do vampirismo, o "tema do fantasma erótico", muito vasto na literatura moderna (PAZ, 1994, p.62), visitante noturno que visa muito mais a consumação amorosa impossível do que meramente a saciedade de uma sede por sangue, vampirismo assim muito mais metafórico do que literal, uma vez que o sangue parece avultar como metáfora do ardor erótico. 0 vampirismo folclórico, ao contrário, continha apenas o elemento da monstruosidade enquanto violência antropofágica, da criatura se alimentando de outra criatura com quem teria laços de parentesco.

O vampirismo metafórico de Aurélia, portanto, parece ter sua matriz verificável nestes primeiros textos românticos sobre o tema. Talvez o mais contundente exemplo de clausura desejante vampírica relacionada a uma aparência repelente esteja em um filme alemão muitos anos posterior à morte de Lúcio Cardoso, Nosferatu, Phantom der Nacht, de Werner Herzog, refilmagem do clássico de Murnau. O filme, de 1979, também associa vampirismo a desejo insaciável, numa perspectiva melancólica, refletindo os impasses e as aporias da condição humana. Visualmente repulsivo, o vampiro deste filme lamenta atravessar os séculos incapaz de consumar o desejo de amar, evidenciando o corpo como clausura, conforme as passagens extraídas de $A$ imitação de Cristo. "O tempo é um abismo tão profundo como mil noites... A morte não é o pior, é bem mais cruel ser incapaz de morrer... A ausência do amor é a dor mais abjeta que existe...", diz o conde-vampiro do filme, que também recorre à postura de ave de rapina, sempre à espreita, não 
hesitando em avançar sobre o objeto do desejo quando o momento se mostra propício, como acontece na cena em que agarra a mão de Jonathan Harker que havia se cortado com uma faca ao partir o pão e suga-lhe o sangue apaixonadamente.

O vampirismo enquanto produto da criação literária, assim, ganha dimensões ontológicas ao se apresentar como metáfora da condição humana de se estar enclausurado em um corpo desejante mesmo após o desaparecimento da juventude e da beleza física. A esse respeito, um dos maiores estudiosos acadêmicos do vampirismo na literatura, James B. Twitchell, insiste em afirmar que o vampiro "vive para o amor, não para o sangue" (TWITCHELL, 1997, p.51).

Se com Aurélia o vampirismo se coloca enquanto metáfora erótica e ontológica, no drama teatral Angélica o tema do vampirismo pela primeira vez comparecia na obra de Lúcio Cardoso de forma explícita, e não apenas metaforizada. Filho da tradição gótica, o vampiro também é um personagem da literatura fantástica por excelência, dada a sua condição de criatura sobrenatural que ameaça o mundo da realidade empírica (ROAS, 2014).

A relação de Lúcio Cardoso com o teatro se configurou conturbada, oscilando entre a empolgação de contribuir para a renovação do teatro brasileiro e as decepções nas montagens dos textos e as subsequentes reprovações críticas por parte dos jornais da época. Após a representação de Angélica, cuja personagem principal fora interpretada pela atriz Luíza Barreto Leite, Lúcio escreveria em seu diário que "não, não, é completamente inútil voltar ao teatro. Angélica marcou definitivamente a minha última tentativa" (CARDOSO, 2012, p.311). Parte do desgosto relacionavase com a crítica, que parecia não apreender seu drama em totalidade. 
A respeito do que escreviam sobre o mesmo, Lúcio desabafa: "artigo de determinado crítico sobre Angélica, respirando uma tal estupidez uma tão grande má vontade, uma desonestidade tão veemente, que me põe perplexo [...] isto é que é o pior no teatro: colocar-nos ao alcance de imbecis desta espécie" (CARDOSO, 2012, p.314). Como acontecera com grande parte das encenações de seus textos dramáticos, este também não obteve grande êxito: "Angélica, levada à cena ontem, num teatro minúsculo e pouco confortável, constitui mais um fracasso para se juntar à série que me vem perseguindo ultimamente" (CARDOSO, 2012, p.311). É provável que tanto o público quanto a crítica tenham assistido Angélica com uma expectativa baseada em pressupostos veristas e tenham estranhado "o artifício e a irrealidade" que caracterizam as peças teatrais de Lúcio Cardoso (PRADO, 2006, p.389).

O estudo do drama de Lúcio Cardoso contribui para o reconhecimento da coesão de seu projeto artístico, visto que manifesta temáticas e atmosferas presentes em outras de suas produções, o que atesta o alto grau de intratextualidade dentro da obra do autor. Antonio Arnoni Prado, no posfácio que integra a edição dos dramas teatrais de Lúcio Cardoso (Teatro reunido, 2006), reconhece que "parece hoje inegável que a sua dramaturgia é a contraparte indispensável à compreensão e ao aprofundamento dos temas presentes no corpo de sua prosa e na origem latente de seus diários" (2006, p.386), o que, de fato, atesta a unidade que entrelaça suas obras. Prado caracteriza os dramas teatrais de Lúcio como sendo dotados "de gestos vigilantes e de olhos sempre dissimulados em razão da maldade e da descrença" (2006, p.386), de modo a reconhecer "a obscuridade das coisas e dos seres, o 
clima de mistério que se integra à paisagem de sua prosa e recobre de incertezas a atmosfera das casas" (2006, p.387), mas parece se decepcionar com o que considera "literatice e insinceridade" nos dramas teatrais de Lúcio (PRADO, 2006, p.389).

É relevante considerar que Lúcio "escolheu inscrever-se na tradição do 'drama psicológico', com crises, mortos, situações paroxísticas, na linha de Ibsen, Strindberg, Tchekhov", afirma Mario Carelli (1988, p.99). Nos diários, Lúcio registrara diversas leituras dramáticas; Carelli pontua alguns desses autores considerando o "temperamento trágico" de Lúcio, o qual o teria levado não apenas aos gregos, mas também ao teatro elisabetano de William Shakespeare, Ben Johnson, Dekker, além do interesse por Christopher Marlowe, Jean-Paul Sartre, Albert Camus e, mais tardiamente, Jean Genet (CARELLI, 1988, p.89).

A trama de Angélica tem como protagonista uma senhora aristocrática, muito semelhante a Aurélia, que acolhe jovens desvalidas em seu grande casarão sob o pretexto de protegê-las. As jovens, no entanto, acabam definhando e morrendo sempre, enquanto Angélica se mantém a cada dia mais remoçada.

Até a publicação do Teatro reunido de Lúcio Cardoso, organizada por Antônio Arnoni Prado em 2006, a peça só estava disponível para leitura nas sessenta e nove laudas datilografadas por Lúcio que se encontram em seu arquivo no Setor de Literatura Brasileira da Fundação Casa de Rui Barbosa, no Rio de Janeiro, de onde colhemos as transcrições a seguir.

O cenário da casa de Angélica apresenta elementos decorativos que poderíamos encontrar nas descrições dos espaços góticos: "móveis 
antigos", "quadros e medalhões nas paredes", "um vasto espelho de moldura dourada", "castiçais variados de cristal e prata" (CARDOSO, 1950, fl.1). Angélica "é uma solteirona de meia-idade, pálida, extravagantemente vestida, com um luxo fantástico e demodée" (fl.1). Traz também, como Aurélia, "jóias excessivas, demonstrando uma visível vaidade" (CARDOSO, 1950, fl.1).

A relação hierárquica demarcada entre Angélica e seu capataz Leôncio muito lembra a de Aurélia e seu capataz Miguel e a de Aurélia e José Roberto, em $O$ desconhecido. Não apenas por uma tentativa de dominação por parte das personagens femininas, mas também pelo fausto que as duas personagens ostentam. A considerar a indumentária, nota-se um luxo aristocrático démodé, já em desuso, relativo a uma ordem social decadente, sobrepujada por um novo mundo no qual Angélica parece não se encaixar. Estaria, assim, encerrada em sua condição antiquada frente às mudanças sociais e, assim, apresentando um aspecto de fantasma do passado a assombrar o presente, um dos traços principais da literatura gótica. Sua própria casa, provinciana, é ornamentada com objetos e móveis, como já listado acima, pertencentes a outras linhagens, como o símbolo de um período histórico já desaparecido que insiste em se prolongar. Sabe-se que a narrativa gótica "nunca se desliga dos problemas da sua época", pois seria "fortemente condicionada pelo seu contexto social" (MONTEIRO, 2004, p.139), o que atesta o desenvolvimento e adaptação do Gótico ao longo dos séculos em cada contexto, estabelecendo a tensão entre uma nova configuração social e o passado que tende por incidir nesta, o que não deixa de revelar as tensões entre tradição e modernidade, um dos eixos temáticos mais importantes da segunda fase do 
Modernismo brasileiro, além de ser um dos dados mais relevantes da cultura brasileira como um todo.

A peça começa sob o signo da clausura: a criada Joana pergunta à sua senhora se esta não tem medo de abrir a janela, ao que Angélica responde estar fechada "neste quarto" desde que a última jovem adoecera. Na cena em que recebe a visita de senhoras da cidade, Angélica explica que a jovem, Maninha, morrera de um "mal misterioso". "Sempre morrem as minhas protegidas" (CARDOSO, 1950, fl.6), lamenta Angélica, embora as moças sejam sempre "tratadas como se fossem rainhas" (fl.7). As senhoras de visita exclamam: "Ultimamente a senhora parece ter remoçado vinte anos!"; "Exatamente, a senhora parece remoçada, outra!" (fl.8). O monólogo de Angélica, após a saída das visitantes, explica a razão do rejuvenescimento e sugere a especificidade de sua natureza "ávida de prazer":

Disseram que estou remoçada... como se tivesse readquirido vinte anos. $\mathrm{O}$ que esta gente fala sem compreender! Quantas poderão como eu alisar assim o oval da face, experimentar as rugas que mal se denunciam, prender estes cabelos ainda negros? Ah, quantas poderiam dizer realmente minha idade? Este vigor, este impulso para a vida... Talvez o que me conserve seja a consciência de que ainda desejo tanto quanto da primeira vez: nada extinguiu a minha sede, o sangue que corre nas minhas veias ainda é quente como da primeira mocidade! É hoje que o milagre se renova, sinto que o mistério é de uma energia constante, o de uma fonte perpetuamente a ferver dentro de mim! (CARDOSO, 1950, fl.8-9)

Angélica pede a seu capataz Leôncio que traga para ela uma nova rapariga, mas que seja "sã" e ao mesmo tempo "de uma 
constituição frágil de quem eu possa cuidar, a quem possa dedicar o meu carinho, os meus cuidados" (CARDOSO, 1950, fl.10). Ressalta que a nova jovem seja "delicada... ainda moça... bonita, se possível" (fl.10). Leôncio sugere uma jovem que brigara com o namorado e com a própria mãe, ao que Angélica ordena: "Traga, traga este lírio selvagem! É dele que eu preciso" (fl.13).

Comentários suspeitos começam a circular pela cidade. A criada Joana se recorda de que ao ver o rosto de Maninha morta se deparara com "uma velha, um ser enrugado", parecendo "que Ihe arrancaram alguma coisa à força, que sugaram dessa coisa morta toda a sua energia" (CARDOSO, 1950, fl.18) - Nos originais, esta última frase encontra-se riscada por seu autor, como se não quisesse ir além da mera sugestão, sem cair no terreno do explícito, mas julgamos relevante transcrevê-la aqui. O final do primeiro ato registra mais um monólogo de Angélica, diante do cadáver de Maninha. Os trechos entre colchetes encontram-se riscados por seu autor, mas optamos por transcrevê-los devido à sua relevância para o tema em questão:

Velha! Velha e triste, como as que murcham no asilo, como as que andam por aí pedindo esmola! [Você ouviu, Maninha, você ouviu bem? Ninguém poderia reconhecer o seu rosto: essa pele queimada e frouxa, esses cabelos colados às têmporas, essa boca escura. Nunca mais você verá a luz do sol nem poderá passar a mão no seu próprio rosto, nem se olhar no espelho! É, todos dizem que eu estou cada dia mais moça, que rejuvenesço, que os meus olhos brilham como se eu ainda tivesse um namorado! Olhe para os meus ombros, veja a minha pele branca, os meus cabelos longos e sedosos! Veja como eu me acaricio, como adoro 
essa pele que é minha, como me beijo e suspiro de alegria!] Ah, Maninha, não adiantou você morrer enquanto fui buscar o copo d'água... [Aqui estou eu, moça, ardente, apesar de você me ter roubado o seu último suspiro, aquele de que mais tinha necessidade!] (CARDOSO, 1950, fl.19).

O trecho acima confirma os jogos de intratextualidade presentes na obra de Lúcio Cardoso, no que Angélica consuma com Maninha, o que Aurélia gostaria de conseguir com Nina: sugar sua juventude e sua beleza. As alusões intertextuais também se confirmam, no que a história de Angélica apresenta semelhanças indiscutíveis com os episódios envolvendo o "supermodelo histórico" do vampirismo segundo Laurence Rickels, a condessa húngara Elisabeth Báthory, levada aos tribunais em 1611 por haver causado a morte de seiscentas e cinqüenta moças em cujo sangue se banhava para se manter bela e jovem (RICKELS, 1999, p.12). Vários filmes foram inspirados em sua história, que guarda também semelhanças com a clausura e a tortura imposta aos jovens pelos libertinos poderosos no castelo de Silling em 120 dias de Sodoma, do Marquês de Sade (BARTHES, 1990, p.21).

No segundo ato, Leôncio traz para Angélica a jovem Lídia, que não compreende o interesse da senhora em sua permanência na casa já que não terá que desempenhar nenhuma função serviçal. Angélica diz precisar de uma dama de companhia. O trecho que se segue denuncia o vampirismo da personagem:

Angélica - Quero-a junto a mim, como uma companheira, uma filha. Sabe o que é ser filha atenta e carinhosa?

Lídia - Mas a senhora nem me conhece! 
Angélica - Que importa? E este sangue quente que corre nas suas veias, esta energia e este calor concentrado?

Lídia - É disto que a senhora precisa?

Angélica - É disto. (CARDOSO, 1950, fl.24)

Angélica persuade Lídia, prometendo lhe deixar seus bens como herança. Ao ser indagada pela jovem sobre a morte das outras três moças, responde: "exalaram junto de mim o último suspiro. E nós, os vivos, que devemos a estes pobres seres fora dos limites? São prisioneiros, e a nossa liberdade é imensa" (CARDOSO, 1950, fl.28), reafirmando, como em $O$ desconhecido, a equivalência entre vida juventude - beleza - liberdade, e entre morte - velhice - fealdade - prisão - clausura. Os mortos, os não-belos, os não-jovens, em Lúcio Cardoso, a partir de uma das vertentes da tradição literária do vampirismo, não podem dar vazão a seu desejo, não podem amar, a não ser que ataquem seus objetos de desejo como aves de rapina. A clausura da noiva de Corinto goethiana, como vimos, era conseqüência de sua condição de morta.

No terceiro ato Lídia está doente, perdendo a energia à medida que Angélica a sufoca com casacos de pele e cobertores (CARDOSO, 1950, fl.47). Leôncio se sente culpado e acaba expondo a Lídia os reais desígnios de Angélica: "mas não compreende, não sente que ela está lhe sugando a energia, que tem necessidade disto como uma seiva para viver?" (fl.49). Lídia e as demais jovens que definharam na casa de Angélica não deixam de apresentar traços em comum com o paradigma gótico da "donzela perseguida". Leôncio passa a antagonizar a sua senhora, a quem se refere desdenhosamente, assinalando sua monstruosidade: "Há muitas 
coisas que não compreendemos ainda e uma delas é o mistério dessas naturezas sequiosas. São seres raros, espécie de plantas que empestam e viciam o ar com o próprio perfume. Mas nem é perfume, é veneno o que escorre no fundo lodoso de suas almas" (1950, fl.56). Ao confrontar Angélica no intuito de retirar Lídia daquela casa, Leôncio ouve da protagonista: "Você não me engana: queria apenas devorá-la antes de mim", ao que ele rebate: "Sua linguagem me dá arrepios" (fl.60). A relação entre Angélica e Leôncio guarda extraordinária semelhança com a ligação entre Aurélia e Miguel, de $O$ desconhecido, no que o criado funciona como cúmplice da senhora criminosa. No caso de Leôncio, há, entretanto, o arrependimento e o confronto, o que não ocorre entre Aurélia e Miguel. Porém, o dado da senhora aristocrática ver o criado como objeto erótico é recorrente em Lúcio Cardoso. Aurélia é amante de Miguel e tenta seduzir José Roberto, do mesmo modo como Angélica tenta, surpreendentemente, seduzir Leôncio:

Posso amá-lo, Leôncio, posso amá-lo como qualquer uma, ou julga que eu sou uma mulher feia? Veja estes braços, estas jóias... Muitos dizem que eu ainda sou moça, que cada dia sou mais moça... Muitos me desejam, seria capaz de apontar na rua os que me olham com cobiça. Veja este rosto, estes olhos que brilham... [...] Passa a mão na minha pele, veja como é sedosa, veja os meus cabelos, sinta o seu perfume! Olhe, são cabelos de mulher, cabelos quentes! (CARDOSO, 1950, fl.63)

Leôncio não apenas se mostra insensível aos arroubos de Angélica como também abandona o sinistro casarão, levando consigo Lídia e Joana. Desesperada, Angélica, "insensível, rompendo violentamente o vestido", arrisca uma última tentativa: "Já experimentou junto à face 
o calor deste sangue? Ah, Leôncio, como você está enganado, como se ilude ao me desprezar assim! Sou moça, sou muito mais moça do que outras que andam por aí... Olhe, apalpe esta pele, estes seios, este corpo sem rugas!" (CARDOSO, 1950, fl.65). Ao sair, Joana desafia sua antiga senhora: "Sobre quem se lançará sua natureza criminosa de agora em diante? Quem sugará, quem matará aos poucos, quem Ihe fornecerá o alento da sua eterna juventude?" (fl.67). Ao partirem todos, o rosto de Angélica subitamente envelhece: "Oh, não quero mais me ver, detesto este rosto formado pelos restos de tantas pessoas mortas!" (fl.68), diz, atirando um objeto ao espelho, que se parte em pedaços. Com um revólver, Angélica se suicida. Agonizante, arrasta-se no chão e, tomando um caco do espelho nas mãos, interroga a sua própria imagem refletida:

Lá está ela, não disse? Lá está a outra, a que me espia com os olhos brancos, sem nada compreender. Não quero que ela me olhe assim, proíbo-a que faça isto! Ah, lá continua ela... Que me quer você, que espera de mim? Quem lhe deu o direito de se instalar aí e vigiar todos os meus atos? Porque me persegue deste modo, qual é o seu nome, quem é você? Vamos, diga, quem é você, quem é? (CARDOSO, 1950, fls.68-69)

Ao exalar seu último suspiro, Angélica, porém, pergunta-se: “Mas ao certo, quem sou eu, meu Deus, quem sou eu?" (1950, fl.69). Nesta peça de Lúcio Cardoso, as vítimas vampirizadas não correspondem a objetos de desejo erótico, mas sim a fontes de perpetuação da juventude para que o erotismo do vampiro possa acontecer livremente. Há vampiros que não sugam sangue de suas vítimas, preferindo priválas de coisas igualmente valiosas, como a juventude, por exemplo (RYAN, 1988, p.XVI). O desespero de Angélica no final equivale ao 
desespero de Aurélia, motivado pela exclusão amorosa dos velhos e feios no etos ocidental apolinizado, que só franqueia o acesso a Eros aos que possuem a beleza e a juventude. O vampirismo em Lúcio Cardoso, nas modalidades apresentadas da postura da ave de rapina e da clausura do desejo, vincula-se, assim, a dimensões ontológicas mais amplas, avultando dentro do grande drama da condição humana.

A poeticidade dos textos de Lúcio Cardoso convive com o caráter postiço dos diálogos demasiadamente impostados, soando sobremaneira teatrais, e, em muitos casos, ostentando inclusive o uso de clichês, que logram conferir um caráter kitsch indiscutivel aos textos. "A literatura de Lúcio Cardoso se constrói, acima de tudo, como literatura", apresentando até mesmo "os elementos mais artificiais e antiquados" (BUENO, 2000, p.24). Com efeito, nas narrativas de Lúcio, "eventuais palavras e gestos grandiloqüentes redundam em artificialidade retórica, às vezes francamente camp" (LOPES, 1999, p.111). Este aspecto, porém, embora dissonante com a tradição realista e desliterarizada da narrativa brasileira após o Modernismo de 22 (CANDIDO, 1989, p.205), contribui para o pertencimento de Lúcio Cardoso dentro da tradição da literatura gótica, desde o início marcada por altas doses de artificialismo e teatralização.

\section{REFERÊNCIAS}

ARGEL, Martha; NETO, Humberto Moura (2008). O vampiro antes do Drácula/ organização, comentários e tradução. São Paulo: Aleph.

AUERBACH, Nina (1995). Our vampires, ourselves. Chicago: The University of Chicago Press.

BARROS JUNIOR, Fernando Monteiro de (2002). Vampiros na casa-grande: clausura e poses do Gótico em Lúcio Cardoso. (Tese - Doutorado em Letras Vernáculas). Faculdade de Letras, Universidade Federal do Rio de Janeiro, Rio de Janeiro. 
BARTHES, Roland (1990). Sade, Fourier, Loyola. Mário Laranjeira (Trad.). São Paulo: Brasiliense.

BELSEY, Catherine (1994). Desire: love stories in Western culture. Oxford: Blackwell.

BRANDÃO, Junito de Souza (1988). Mitologia grega: volume II. 2.ed. Petrópolis: Vozes. BUENO, Luís (2000). "A tormenta da existência". Folha de S. Paulo Mais!. São Paulo, 2 de abril, p.24.

CÂNDIDO, Antonio (1989). A educação pela noite \& outros ensaios. 2.ed. São Paulo: Ática, 1989.

CARDOSO, Lúcio (1950). Angélica. (S. I., 69fls. + 126 fls. - cópia). Peça teatral. Arquivo Lúcio Cardoso, Centro de Literatura Brasileira, Fundação Casa de Rui Barbosa, Rio de Janeiro, s.d.

CARDOSO, Lúcio (1969). Três histórias de província: Mão vazias, O desconhecido e A professora Hilda. 2.ed. Rio de Janeiro: Bloch.

CARDOSO, Lúcio (2012). Diários/Lúcio Cardoso; organização, apresentação, cronologia, estabelecimento de textos e notas Ésio Macedo Ribeiro. Rio de Janeiro: Civilização Brasileira.

CARELLI, Mario (1988). Corcel de fogo: vida e obra de Lúcio Cardoso (1912-1968). Júlio Castañon Guimarães (Trad.). Rio de Janeiro: Guanabara.

FRAYLING, Christopher (1992). Vampyres: Lord Byron to Count Dracula. London: Faber and Faber.

GOETHE, Johann Wolfgang von (1999). 103 great poems / 103 meistergedichte: a duallanguage book. StanleyAppelbaum (Trad.). Mineola, New York: Dover Publications. GLADWELL, Adèle Olivia (1999). "The erogenous disease”. In: (Eds.).

Blood \& roses: the vampire in $19^{\text {th }}$ century literature. S.I.: Creation Books.

HINDLE, Maurice (1993). "Introduction”. In: STOKER, Bram. Dracula. London: Penguin Books.

KEMPIS, Tomas de (1948). Imitação de Cristo. Padre Leonel Franca (Trad.). S.J. 4.ed. Rio de Janeiro: José Olympio.

LECOUTEUX, Claude (2005). História dos vampiros: autópsia de um mito. Álvaro Lorencini (Trad.). São Paulo: Editora UNESP. 
LIMA, Luiz Costa (1976). A perversão do trapezista: o romance em Cornélio Penna. Rio de Janeiro: Imago.

LOPES, Denilson (1999). Nós os mortos: melancolia e neo-barroco. Rio de Janeiro: Sette Letras.

MONTEIRO, Maria Conceição (2004). Na aurora da modernidade: a ascensão dos romances gótico e cortês na literatura inglesa. Rio de Janeiro: Caetés.

OTTO, Walter (1995). Dionysus: myth and cult. Robert B. Palmer (Trad.). Bloomington/Indianapolis: Indiana University Press.

PAGLIA, Camille (1992). Personas sexuais: arte e decadência de Nefertite a Emily Dickinson. Marcos Santarrita (Trad.). São Paulo: Companhia das Letras.

PAZ, Octavio (1994). A dupla chama: amor e erotismo. Wladir Dupont (Trad.). São Paulo: Siciliano.

PENNA, Cornélio (1958). Romances completos. Rio de Janeiro: José Aguilar.

PLATÃO (1989). Fedro. Pinharanda Gomes (Trad.). 4.ed. Lisboa: Guimarães.

PRADO, Antonio Arnoni (2006). "Posfácio" In: CARDOSO, Lúcio. Teatro reunido/ Lúcio Cardoso. Curitiba: Ed. UFPR.

PRAZ, Mario (1996). A carne, a morte e o diabo na literatura romântica. Philadelpho Menezes (Trad.). Campinas: Editora da UNICAMP.

RICKELS, Laurence A (1999). The vampire lectures. Minneapolis, MN: University of Minnesota Press.

ROAS, David (2014). A ameaça do fantástico: aproximações teóricas. Julián Fuks (Trad.). São Paulo: Editora Unesp.

RYAN, Alan (1988). "Introduction". In: (Eds.). The Penguin book of vampire stories. New York: Penguin.

SEFFRIN, André (2000). "Demasiadamente humano" (prefácio). In: CARDOSO, Lúcio. Novelas: O desconhecido e Mãos vazias. Rio de Janeiro: Civilização Brasileira. TODOROV, Tzvetan (1975). Introdução à literatura fantástica. Maria Clara Correa Castello (Trad.). São Paulo: Perspectiva.

TWITCHELL, James B (1997). The living dead: a study of the vampire in Romantic literature. Durham, N.C.: Duke University Press. 